\title{
Stereo-selective conversion of mandelonitrile to $(R)-(-)$-mandelic acid using immobilized cells of recombinant Escherichia coli
}

\author{
Sandip V. Pawar $\cdot$ Vachan Singh Meena $\cdot$ \\ Shubhangi Kaushik • Ashwini Kamble • \\ Sandeep Kumar · Yusuf Chisti · U. C. Banerjee
}

Received: 22 January 2012/ Accepted: 14 March 2012/Published online: 29 March 2012

(C) The Author(s) 2012. This article is published with open access at Springerlink.com

\begin{abstract}
Immobilized cells of a recombinant Escherichia coli expressing nitrilase from Pseudomonas putida were used to catalyze the hydrolysis of mandelonitrile (2hydroxy-2-phenylacetonitrile) to $(R)-(-)$-mandelic acid. The cells had been immobilized by entrapment in an alginate matrix. Conditions for the hydrolysis reaction were optimized in shake flasks and in a packed bed reactor. In shake flasks the best conditions for the reaction were a temperature of $40^{\circ} \mathrm{C}, \mathrm{pH} 8$, biocatalyst bead diameter of $4.3 \mathrm{~mm}$, sodium alginate concentration in the gel matrix of $2 \%(\mathrm{w} / \mathrm{v}, \mathrm{g} / 100 \mathrm{~mL})$, a cell dry mass concentration in the bead matrix of $20 \mathrm{mg} / \mathrm{mL}$, an initial substrate concentration of $50 \mathrm{mM}$ and a reaction time of $60 \mathrm{~min}$. Under these conditions, the conversion of mandelonitrile was nearly $95 \%$. In the packed bed reactor, a feed flow rate of $20 \mathrm{~mL} /$ $\mathrm{h}$ at a substrate concentration of $200 \mathrm{mM}$ proved to be the best at $40{ }^{\circ} \mathrm{C}, \mathrm{pH} 8$, using $4.3 \mathrm{~mm}$ beads $(2 \% \mathrm{w} / \mathrm{v}$ sodium alginate in the gel matrix, $20 \mathrm{mg}$ dry cell concentration per $\mathrm{mL}$ of gel matrix). This feed flow rate corresponded to a residence time of $0.975 \mathrm{~h}$ in the packed bed.
\end{abstract}

Keywords Nitrilase - Mandelic acid - Mandelonitrile . Packed bed reactor Immobilized cells

S. V. Pawar · V. S. Meena - S. Kaushik - A. Kamble ·

S. Kumar · U. C. Banerjee $(\bowtie)$

Department of Pharmaceutical Technology (Biotechnology),

National Institute of Pharmaceutical Education and Research,

Sector-67, SAS Nagar, 160062 Punjab, India

e-mail: ucbanerjee@niper.ac.in

Y. Chisti

School of Engineering, Massey University, Private Bag 11 222,

Palmerston North, New Zealand

\section{Introduction}

The conventional harsh chemical methods are extensively substituted by environment-friendly biocatalysts for the synthesis of pharmaceutically important intermediates (Kumar et al. 2010). The interest towards use of nitrilase has been tremendously increasing since past decade leading to the easy hydrolysis of nitriles (Martinkova and Mylerova 2003; Chen et al. 2008; Kaplan et al. 2006; Rustler et al. 2007); it offers significant advantages over other routes as cheap starting material, absence of cofactor involvement and the possibility of carrying reactions under mild condition (Banerjee et al. 2002; He et al. 2010; He et al. 2007). Additionally, the existence of nitrile-hydrolyzing enzymes that show enatio- and regio-selectivity offers synthetic possibilities that are difficult to achieve by conventional catalytic approaches (Naik et al. 2008; Kiziak et al. 2005). Immobilized whole cells of microorganisms are widely used as catalysts for various biotransformation processes (Bucko et al. 2005; Niladevi and Prema 2008). When applicable, whole cell biocatalysis avoids the need to extract and purify intracellular enzymes and is therefore less expensive compared with immobilized enzyme catalysts (Givry et al. 2008; Takeru et al. 2005).

$(R)$-(-)-mandelic acid is an important pharmaceutical intermediate for the production of semi-synthetic cephalosporins, penicillins (Terreni et al. 2001; Tang et al. 2009) antitumor agents (Surivet and Vatele 1998) and antiobesity drugs (Mills et al. 1983). Its derivatives are used also as chiral resolving agents (Kinbara et al. 1996; Xue et al. 2011). Polymers of mandelic acid have been developed into antimicrobial contraceptives for vaginal prophylaxis (Zaneveld et al. 2002). Derivatives of mandelic acid have been shown to have antifungal activity (Kope et al. 1991), broad spectrum $\beta$ lactamase inhibitor activity (Mollard et al. 2001) and antioxidative properties (Ley and Bertram 2001). 
Mandelic acid is produced by chemical as well as enzymatic methods; several approaches to obtain enatiomerically pure mandelic acid have been reported in the literature (Yadav and Sivakumar 2004; Xiao et al. 2005, 2008; Oda et al. 1992; Patterson et al. 1981; Miyamoto and Ohta 1992). Nitrilase-mediated production of $(R)-(-)$ mandelic acid has significant advantage over chemical methods of production; it offers excellent enatioselectivity and above all possibility of carrying out dynamic kinetic resolution which provides $100 \%$ theoretical yield of the product (Yamamoto et al. 1991; Banerjee et al. 2006; Singh et al. 2005; Xue et al. 2011) (Fig. 1). In recent years, the hydrolysis of mandelonitrile has been reported using recombinant nitrilase from Pseudomonas fluorescens EBC191 (Bucko et al. 2005), Alcaligenes faecalis ATCC8750 (Rey et al. 2004), newly isolated nitrilase producer Alcaligenes sp. ECU0401 (He et al. 2007; He et al. 2010) and A. faecalis ZJUTB10 (Xue et al. 2011). This study reports the use of immobilized whole cells of the recombinant Escherichia coli BL21 (DE3) for producing $(R)-(-)$-mandelic acid from mandelonitrile in shake flask and packed bed reactor. The recombinant bacterium used harbored the nitrilase gene from $P$. putida MTCC 5110 in the IPTG-inducible plasmid pET $21 \mathrm{~b}(+)$ expression vector. $P$. putida was reported as an ideal candidate for stereo-selective hydrolysis of mandelonitrile, considering its higher growth rate, higher reaction rate and higher stability as compared with other nitrilase-producing microorganisms. $P$. putida nitrilase attains comparable specific activity within a shorter period of time and the fermentation time was also reported to be lower for biocatalyst generation (Kaul et al. 2004).

\section{Materials and methods}

Chemicals

Mandelonitrile, sodium alginate, glutaraldehyde (GA) and polyethyleneimine (PEI) were purchased from Sigma-
Aldrich Chemical Co. (Milwaukee, USA). Growth media components were obtained from Hi-Media Inc. (Mumbai, India). Solvents, buffer salts, inorganic salts and other chemicals used were of analytical grade.

Microorganism and cultivation conditions

Recombinant E. coli BL21 (DE3) was used for the present study. The bacterium harbored the nitrilase gene of $P$. putida MTCC 5110 and had been cloned in our laboratory (Genbank accession no. EF467660) (Banerjee et al. 2009). The stock culture was maintained on plates of Luria-Bertani agar supplemented with ampicillin. The microorganism was initially grown in shake flasks $\left(37^{\circ} \mathrm{C}, 200 \mathrm{rpm}\right)$ for $16 \mathrm{~h}$ in a medium of the following composition: yeast extract $(10 \mathrm{~g} / \mathrm{L})$, tryptone $(16 \mathrm{~g} / \mathrm{L})$ and sodium chloride $(5 \mathrm{~g} / \mathrm{L})$. After $16 \mathrm{~h}, 10 \%(\mathrm{v} / \mathrm{v})$ of the culture was inoculated into fresh flasks containing the aforementioned specified medium. The inducer isopropyl- $\beta$-D-1-thiogalactopyranoside (IPTG) was added to each flask after $1 \mathrm{~h}$ of inoculation and the final IPTG concentration in the flask was $1 \mathrm{mM}$. Cells were harvested after $4 \mathrm{~h}$ by centrifugation at $10,000 \mathrm{~g}\left(4{ }^{\circ} \mathrm{C}\right)$ and washed with Tris- $\mathrm{HCl}$ buffer (100 mM, pH 7) before use.

\section{Immobilization of whole cells}

Washed cells harvested as specified above, were immobilized by entrapment in a sodium alginate matrix (Varma and Gaikwad 2010; Givry et al. 2008). For the entrapment, $200 \mathrm{mg}$ (dry weight basis) of cells was resuspended in $10 \mathrm{~mL}$ of Tris- $\mathrm{HCl}$ buffer $(100 \mathrm{mM}, \mathrm{pH} 7)$. This slurry was added to a $2 \%(\mathrm{w} / \mathrm{v}, \mathrm{g} / 100 \mathrm{~mL})$ solution of sodium alginate (prepare in Tris- $\mathrm{HCl}$ buffer, $100 \mathrm{mM}, \mathrm{pH} 7$ ) with vigorous stirring to ensure complete mixing. The resulting suspension was added dropwise via a syringe to an aqueous solution of $\mathrm{CaCl}_{2}(0.2 \mathrm{M})$. Ca-alginate beads thus formed were allowed to stand in $\mathrm{CaCl}_{2}$ solution for $1 \mathrm{~h}$ for hardening. The hardened beads were washed with distilled water and used for the biotransformation reaction.
Fig. 1 Reaction scheme for enantioselective hydrolysis of $(R, S)$-mandelonitrile for synthesis of $(R)$-mandelic acid

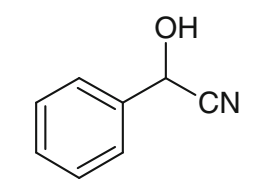

$(R, S)$-Mandelonitrile

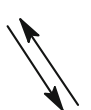

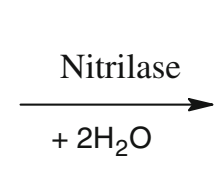<smiles>N#C[C@H](O)c1ccccc1</smiles>

(S)-(+)-Mandelonitrile<smiles>O=C(O)C(O)c1ccccc1</smiles>

(R)-(-)-Mandelic acid
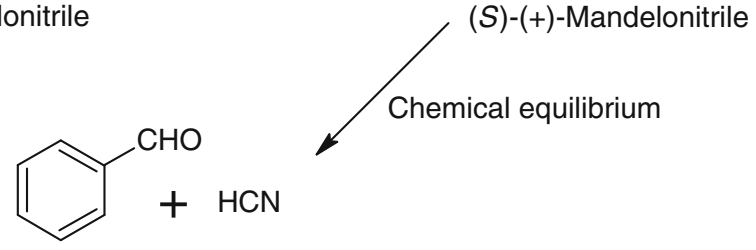

Benzaldehyde 
Biotransformation conditions

Immobilized cells (200 mg dry weight basis) were suspended in $10 \mathrm{~mL}$ of Tris- $\mathrm{HCl}$ buffer (100 mM, pH 7). The final concentration of immobilized cells was $20 \mathrm{mg} / \mathrm{mL}$. Mandelonitrile is not soluble in aqueous solvent (sparingly soluble); hence $10 \%(\mathrm{v} / \mathrm{v})$ methanol was used as a cosolvent to make it soluble (Kaul and Banerjee 2008). It was added to an initial concentration of $30 \mathrm{mM}$ in reaction mixture. The mixture was incubated in shake flasks held at $40{ }^{\circ} \mathrm{C}, 200 \mathrm{rpm}$, for $3 \mathrm{~h}$. Bead-free samples were taken at regular intervals and analyzed by HPLC.

\section{Analytical methods}

The concentration of mandelic acid formed in the reaction mixture was measured by high-performance liquid chromatography (Shimadzu 10AD VP, Kyoto, Japan). Mandelic acid, mandelamide and mandelonitrile were assayed on a LiChroCART $^{\circledR} \mathrm{C}_{18}$ column $(250 \times 4 \mathrm{~mm}, 5 \mu \mathrm{m})$ (Merck, Darmstadt, Germany). The elution solvent was a mixture of water, methanol and phosphoric acid (59.9:40:0.1, by volume). The solvent flow rate was $0.8 \mathrm{~mL} / \mathrm{min}$. The retention times of mandelamide, mandelic acid and mandelonitrile were 4.4, 6.1 and $10.2 \mathrm{~min}$, respectively. Elution was monitored by measuring the absorbance at $210 \mathrm{~nm}$.

The optical purity of mandelic acid was determined by analyzing the enantiomers on Chiralcel OD-H column $(250 \times 0.46 \mathrm{~mm}, 5 \mu \mathrm{m})$ (Diacel Chemical Industries, New Jersey, USA) at a flow rate of $0.5 \mathrm{~mL} / \mathrm{min}$ with a mobile phase of hexane, isopropanol and tri-fluroacetic acid (90:10:0.2, by volume). The retention times for $(S)-(+)-$ isomer and $(R)-(-)$-isomer were 15.5 and $17.5 \mathrm{~min}$, respectively. Absorbance was monitored at $254 \mathrm{~nm}$. Enantiomeric excess (ee, \%) was calculated as follows: ee $=\left|f_{\mathrm{R}}-f_{\mathrm{S}}\right| \times 100$, where $f_{\mathrm{R}}$ and $f_{\mathrm{S}}$ are the mole fractions of the $R$ and $S$ enantiomers in the product such that $f_{\mathrm{R}}+f_{\mathrm{S}}=1$.

\section{Results and discussion}

\section{Effect of alginate concentration}

In separate experiments, the whole cells of recombinant $E$. coli at a dry mass concentration of $20 \mathrm{mg} / \mathrm{mL}$ were immobilized using various concentrations of sodium alginate $(1.0-2.5 \% \mathrm{w} / \mathrm{v}, \mathrm{g} / 100 \mathrm{~mL})$. The nominal bead size was $4.3 \mathrm{~mm}$. The biocatalyst beads made from $2 \%$ sodium alginate effectively entrapped the cells, was structurally stable and afforded a good conversion of the substrate. The beads formed at a higher concentration of sodium alginate were satisfactory in every respect, but were not as good at converting the substrate as the aforementioned beads. This was likely because the harder gels formed at sodium alginate concentrations of $>2 \%$ reduced the diffusion of the substrate in the beads. Due to the liable nature of nitrilase, milder methods are generally used for the immobilization of whole cells/enzymes. The potential adverse effects from the matrix or reagents used are less in the entrapment method of the cell immobilization. It has been reported in the literature (Panova et al. 2007; Ben-Bassat et al. 2008) that by encapsulation of whole cells, there were effective recovery and recycle of the enzyme in the case of glycolic acid production. In view of this, cells immobilized at an alginate concentration of $2 \%$ were used in all subsequent experiments, unless stated otherwise.

\section{Effect of bead size}

Immobilized biocatalysts commonly experience mass transfer limitations. In such cases, efficacy of catalysis declines as the size of the catalyst bead is increased (Won et al. 2005). Therefore, the choice of the bead size is important. In this study, alginate beads of various nominal sizes $(3.5,4.3,4.8,5.3$ and $5.7 \mathrm{~mm})$ were produced by controlling the drop size from the syringe. Preliminary studies with these beads showed the percent conversion of the substrate to decrease with increasing size of beads for otherwise identical conditions. Therefore, a bead size of $4.3 \mathrm{~mm}$ was used in all subsequent works as this size afforded a conversion value that was similar to the conversion attained with $3.5 \mathrm{~mm}$ beads, but the larger beads were easier to handle.

\section{Effect of cell loading}

The effect of cell loading in the alginate beads on their biocatalytic performance was examined. The reaction was carried out at an initial substrate concentration of $30 \mathrm{mM}$. The other conditions were a pH of 7 and $37{ }^{\circ} \mathrm{C}$. The bead size was always $4.3 \mathrm{~mm}$ and the beads had been formed by suspending the specified concentration of cells in a $2 \%$ solution of sodium alginate. Cell loading values (dry weight concentration) of 5, 10, 20, 40 and $60 \mathrm{mg} / \mathrm{mL}$ were tested. The biocatalytic activity increased with the increasing concentration of cells up to $20 \mathrm{mg} / \mathrm{mL}$ (Fig. 2). Higher cell concentrations did not further increase activity likely because the cells interfered with the diffusion of the substrate into the beads. With a cell concentration of $20 \mathrm{mg} / \mathrm{mL}$, the conversion did not further increase after about 60 min of reaction (Fig. 2). In subsequent work, therefore, the reaction time was fixed at $60 \mathrm{~min}$ and the cell concentration of $20 \mathrm{mg} / \mathrm{mL}$ was used.

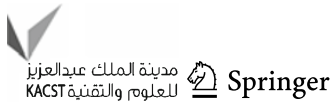




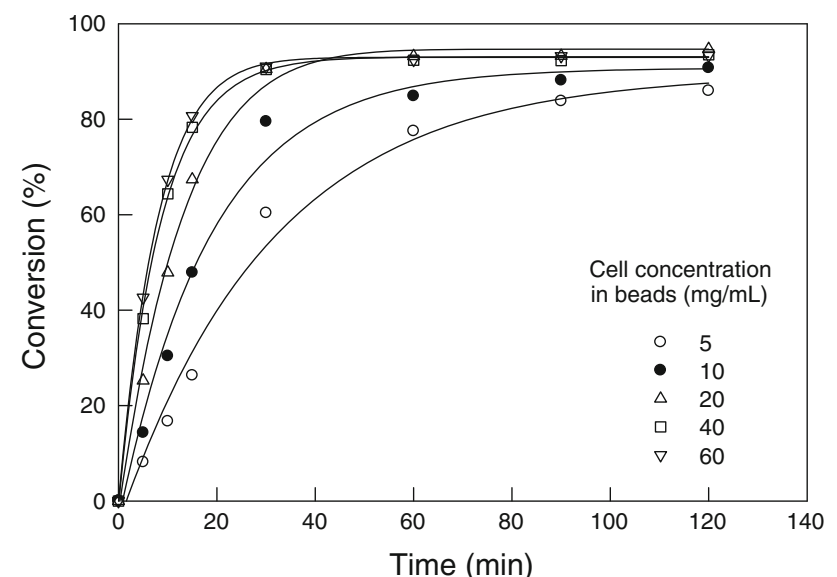

Fig. 2 Effect of immobilized cell concentration on the conversion of mandelonitrile

Effects of $\mathrm{pH}$ and temperature

In enantioselective hydrolysis of racemic mandelonitrile, the unreacted mandelonitrile undergoes spontaneous racemization via benzaldehyde and hydrogen cyanide formation. Generally racemization is favored at a slightly alkaline $\mathrm{pH}$. Therefore, the effect of $\mathrm{pH}$ on substrate conversion was examined at various $\mathrm{pH}$ values ranging from 6.5 to 8.5 . The optimal $\mathrm{pH}$ for maximizing the conversion was found to be 8 (Fig. 3a). The conversion was reduced both above and below the optimal $\mathrm{pH}$ value. The enantiomeric excess was always nearly $100 \%$ and was not sensitive to $\mathrm{pH}$ in the range studied. The temperature for these studies was $37{ }^{\circ} \mathrm{C}$.

As enzyme catalysis is quite sensitive to temperature, the effect of this variable on conversion was examined over the range from 25 to $45^{\circ} \mathrm{C}$. As shown in Fig. $3 \mathrm{~b}$, the maximum conversion value was observed at $40{ }^{\circ} \mathrm{C}$. The other conditions for the reaction were an initial substrate concentration of $50 \mathrm{mM}$, a pH value of $8,20 \mathrm{mg} / \mathrm{mL}$ cell loading in the beads, $1 \mathrm{~g}$ of beads per $\mathrm{mL}$ of reaction liquid, $4.3 \mathrm{~mm}$ bead size and $60 \mathrm{~min}$ of reaction time. The enantiomeric purity of the product was not particularly sensitive to the reaction temperature (Fig. 3b). It has been reported in the literature (Vejvoda et al. 2006) that polyvinyl alcohol and polyethylene glycol co-polymer were used to immobilize cells of Fusarium solani with $75 \%$ recovery of nitrilase activity. $\mathrm{pH}$ optimum values shifted from $\mathrm{pH} 7$ to $\mathrm{pH} 9-10$ and the immobilized cells were very active at $\mathrm{pH} 11$, while free cells at this $\mathrm{pH}$ showed negligible activity. The immobilization had no significant effect on the temperature optimum and thermostability of the nitrilase.

\section{Effect of substrate concentration}

The effect of initial substrate concentration $(10-100 \mathrm{mM})$ on conversion at $60 \mathrm{~min}\left(\mathrm{pH}\right.$ of $\left.8,40^{\circ} \mathrm{C}\right)$ was determined
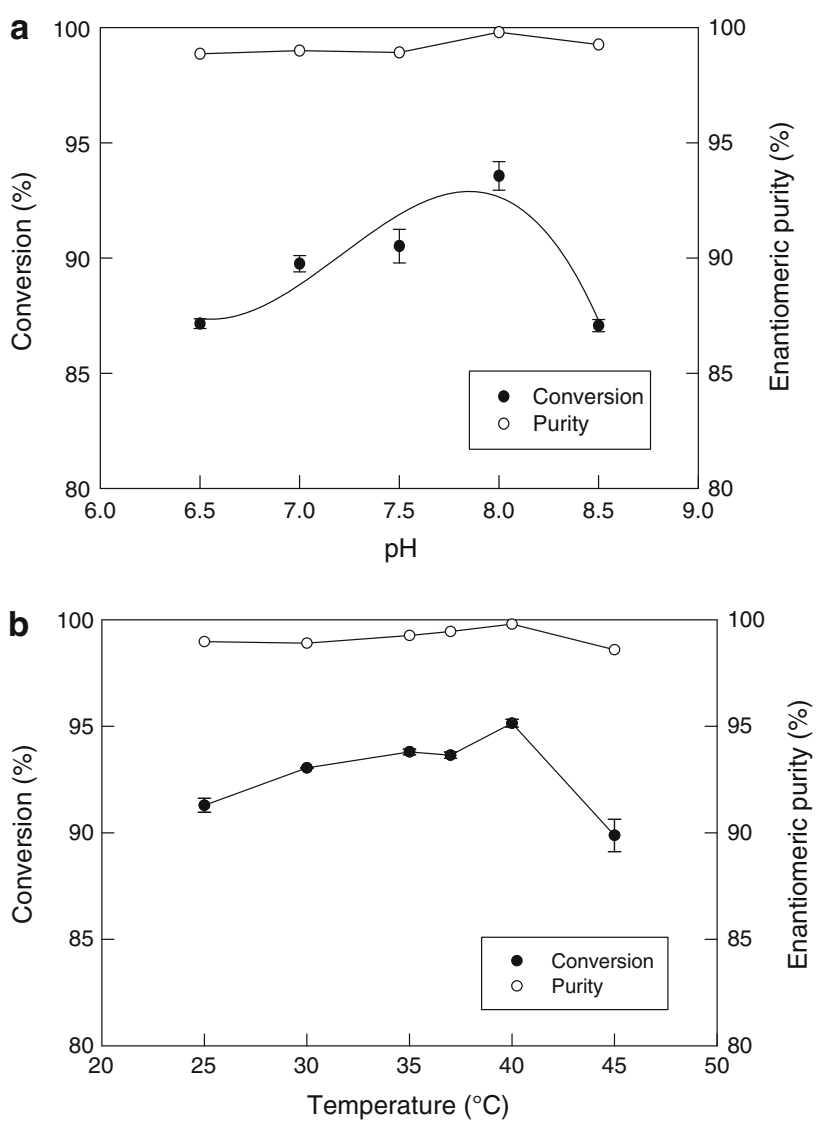

Fig. 3 a Effect of $\mathrm{pH}$ on the conversion of mandelonitrile and the enantiomeric excess (purity) of the product. b Effect of temperature on the conversion of mandelonitrile and the enantiomeric excess (purity) of the product

using beads loaded in the reaction mixture. The cell loading was $20 \mathrm{mg} / \mathrm{mL}$ and the bead size was $4.3 \mathrm{~mm}$. The conversion measured at $60 \mathrm{~min}$ was not too sensitive to the substrate concentration $\leq 50 \mathrm{mM}$ (Fig. 4), but was progressively reduced as the substrate concentration was further increased. An excessive amount of substrate apparently inhibited the reaction. It is known that nitriles are toxic in nature and would limit the immobilized biocatalyst for the transformation reaction and there is a decrease in nitrilase activity due to the substrate inhibition (Zhang et al. 2011). A substrate concentration of $50 \mathrm{mM}$ was therefore used in subsequent work, unless specified otherwise.

\section{Effect of cross linking treatment}

In attempts to further stabilize the biocatalyst beads, in separate experiments the beads $(4.3 \mathrm{~mm}$, made of $2 \%$ sodium alginate) containing the immobilized cells $(20 \mathrm{mg} /$ $\mathrm{mL}$ ) were further treated with various concentrations $(0.1-1.0 \mathrm{M})$ of the crosslinking reagent glutaraldehyde (GA). For the cross linking, the beads were suspended in an 


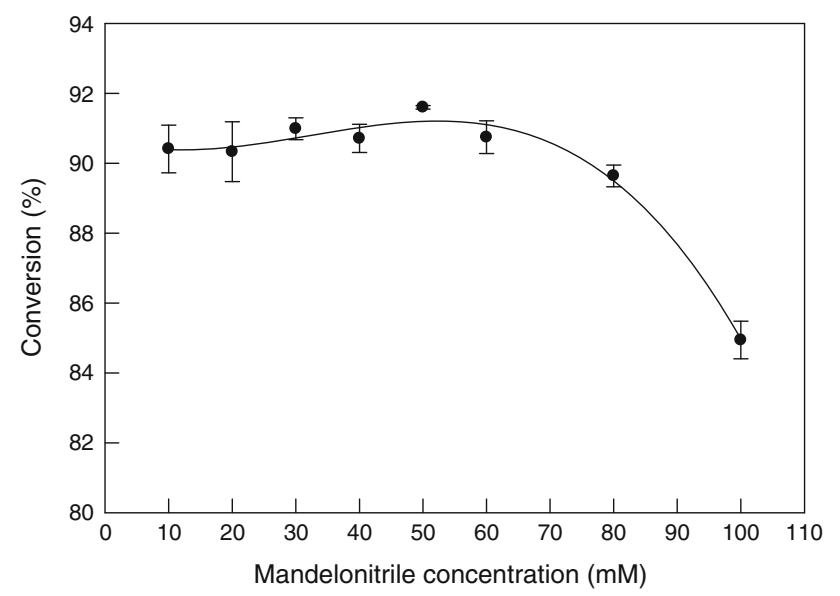

Fig. 4 Effect of initial mandelonitrile concentration on the conversion

aqueous solution of glutaraldehyde of a specified concentration for $2 \mathrm{~h}$ at room temperature. The beads were then washed thoroughly with water and used for the hydrolysis of mandelonitrile. The reaction conditions for the hydrolysis were $40{ }^{\circ} \mathrm{C}, \mathrm{pH} 8,60 \mathrm{~min}$, cross-linked immobilized cells $20 \mathrm{mg} / \mathrm{mL}$ and an initial substrate concentration of $50 \mathrm{mM}$. Beads treated with $0.3 \mathrm{M}$ glutaraldehyde achieved a substrate conversion of around $96 \%$ (Fig. 5a), comparable with the conversion value [seen with otherwise identical beads that were not crosslinked (Fig. 3a, data at $\mathrm{pH}$ 8)]. The crosslinking treatment of the beads had no effect on the enantiomeric purity of the product formed (Fig. 5a).

In separate experiments, the alginate beads, as mentioned above, that had been pretreated with $0.3 \mathrm{M}$ glutaraldehyde ( $2 \mathrm{~h}$, room temperature) and thoroughly washed, were further treated with various concentrations $(5-50 \mathrm{~g} / \mathrm{L}$ aqueous solutions) of PEI for $2 \mathrm{~h}$ at room temperature. The washed beads were then used for the substrate conversion under the above-specified conditions. The conversion was about the same as for the control beads (i.e. treated with $0.3 \mathrm{M}$ glutaraldehyde alone; Fig. 5a) so long as the concentration of the PEI during the second crosslinking treatment remained at $\leq 20 \mathrm{~g} / \mathrm{L}$ (Fig. $5 \mathrm{~b}$ ).

\section{Reusability of catalysts}

Reusability of freely suspended cells, the cells immobilized within alginate beads and the cells immobilized within glutaraldehyde $(0.3 \mathrm{M})$ crosslinked alginate beads was tested by measuring the conversion at the end of each use cycle $(1 \mathrm{~h}$ duration) of a repeated batch reaction. The reaction conditions were always: $40{ }^{\circ} \mathrm{C}$, a pH of $8,50 \mathrm{mM}$ initial substrate concentration. After the reaction, the biocatalyst was recovered by centrifugation (for cells) or filtration (for beads), washed and reused for the next reaction
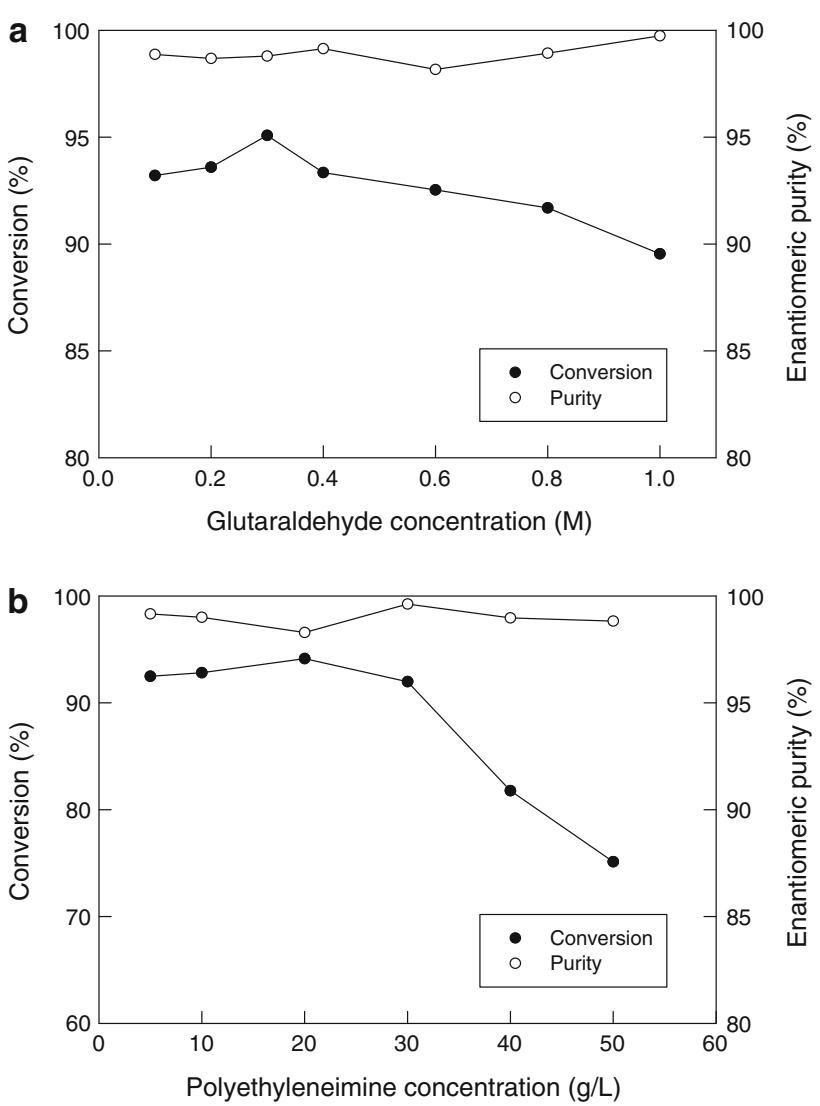

Fig. 5 a Effect of glutaraldehyde crosslinker concentration on the conversion of mandelonitrile and the enantiomeric purity of the product. b Effect of combined treatment of cells with glutaraldehyde $(0.3 \mathrm{M})$ and various concentrations of polyethyleneimine, on the conversion of mandelonitrile and the enantiomeric purity of the product

cycle at the above-specified conditions. The concentration of the immobilized beads $(20 \mathrm{mg}$ cells per $\mathrm{mL}$ of bead volume) was always $1 \mathrm{~g}$ per $\mathrm{mL}$ of the reaction liquid. As shown in Fig. 6, the freely suspended cells rapidly lost activity. The alginate immobilized cells (no crosslinking) retained a high level of activity for around eight cycles of repeated use. The beads that had undergone the crosslinking treatment were somewhat more stable than the untreated beads (Fig. 6).

Packed bed reactor

A packed bed reactor was used for further assessing the performance of the immobilized biocatalyst beads in continuous flow hydrolysis of mandelonitrile. The reactor had a working volume (i.e. nominal volume of the packed bed) of $75 \mathrm{~mL}$ and was made of a glass column with an internal diameter of $26 \mathrm{~mm}$. The height of the packed zone was $200 \mathrm{~mm}$. The reactor was jacketed for temperature control at $40{ }^{\circ} \mathrm{C}$. The packing consisted of beads [cell loading of $20 \mathrm{mg} / \mathrm{mL}, 2 \%$ concentration of sodium alginate, $4.3 \mathrm{~mm}$ 


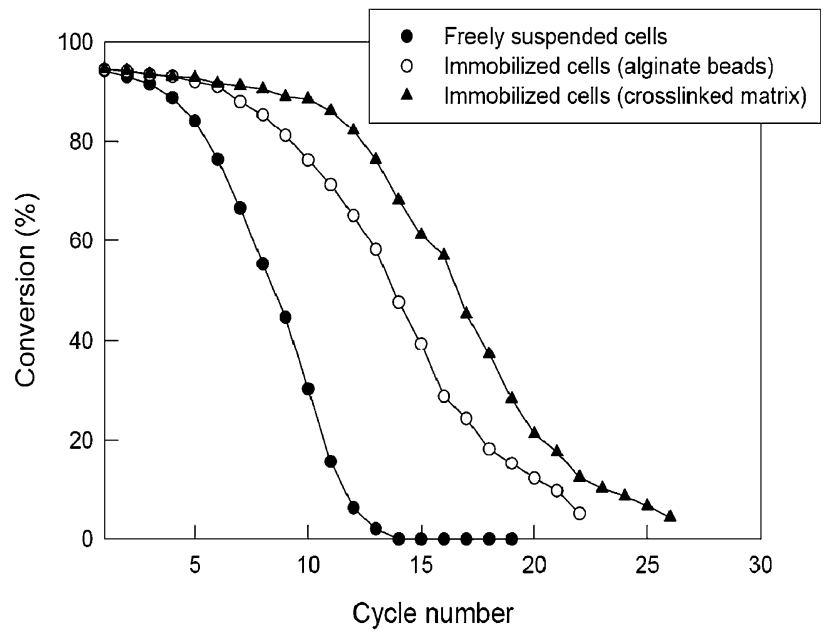

Fig. 6 Effects of catalyst type and reuse cycle number on the conversion of mandelonitrile to mandelic acid

beads, $100 \mathrm{~g}$ (fresh weight) of beads] of either the noncrosslinked catalyst or the catalyst that had undergone the crosslinking treatment with $0.3 \mathrm{M}$ glutaraldehyde. An aqueous solution of substrate $(50-500 \mathrm{mM}, \mathrm{pH}$ 8) was pumped in at the bottom of the vertically mounted reactor using a peristaltic pump. The feed flow rate was varied in different experiments. Samples were taken at the outlet to determine the steady-state conversion at various specified concentrations of the substrate in the feed.

\section{Effect of substrate feed flow rate}

The conversion of the substrate at steady state was found to increase as the flow rate of the substrate increased in the range of $5-20 \mathrm{~mL} / \mathrm{h}$ (data not shown). This was likely a result of improved diffusive mass transfer of the substrate to the biocatalyst beads. Further increase in substrate flow rate to up to $100 \mathrm{~mL} / \mathrm{h}$ actually decreased conversion at an inlet substrate concentration of $50 \mathrm{mM}$ as the residence time of the substrate in the reactor was insufficient for complete conversion to occur. These experiments used the non-crosslinked alginate beads as specified in the previous section. In view of these results, further experiments were carried out at a fixed feed flow rate value of $20 \mathrm{~mL} / \mathrm{h}$.

\section{Effect of substrate concentration in the feed}

The packed bed reactor with the non-crosslinked alginate bead catalyst was used under the above-specified conditions, but at different concentrations $(50-500 \mathrm{mM})$ of the substrate in the feed. Conversion was measured at the exit once one bed volume of the feed had passed through after any change in the feed substrate concentration. The flow rate used $(20 \mathrm{~mL} / \mathrm{h})$ and the nominal bed volume of $75 \mathrm{~mL}$ equated to a nominal residence time (based on the void

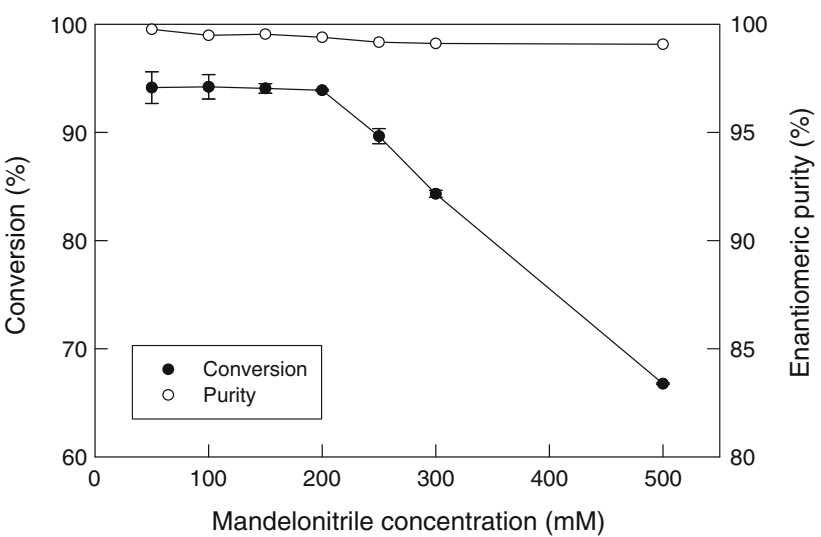

Fig. 7 Effect of substrate concentration in the feed on the conversion of mandelonitrile and the enantiomeric purity of the product

volume of the bed) of $0.975 \mathrm{~h}$ assuming a cubic close packing of the spherical beads in the bed and therefore a void volume fraction of the bed of 0.26 . Under these conditions, the substrate conversion was around $93 \%$ irrespective of the substrate concentration in the feed so long as the concentration was in the range of $50-200 \mathrm{mM}$ (Fig. 7).

Once the substrate concentration in the feed reached $200 \mathrm{mM}$, all the available catalyst in the bed was being used. Therefore, the conversion declined once the substrate concentration in the feed exceeded about $200 \mathrm{mM}$ (Fig. 7) as an increasing proportion of the unconverted substrate left the bed. Nevertheless, compared with the shake flask studies in which the maximum concentration of the substrate was $50 \mathrm{mM}$ at cell concentration of $20 \mathrm{mg} / \mathrm{mL}$ (Fig. 4), the packed bed could be operated at a fourfold higher substrate concentration possibly because of the higher spatial concentration of the catalyst in the bed.

\section{Effect of reactor reuse}

Reusability of the packed bed was tested by operating it continuously for $1 \mathrm{~h}$ at a flow rate of $20 \mathrm{~mL} / \mathrm{h}$ and a substrate concentration in the feed of $200 \mathrm{mM}$. After each such operation, the bed was drained and the catalyst was washed. The next identical operational cycle was then carried out. The conversion was measured using samples collected at the exit of the reactor once a steady state had been attained. Both the immobilized beads and the immobilized crosslinked beads $(0.3 \mathrm{M}$ glutaraldehyde treated) were tested in separate experiments. As shown in Fig. 8, the immobilized bead catalyst could be used for nearly seven cycles without sacrificing the conversion. In contrast, the crosslinked bead catalyst could be used for up to 12 cycles without a significant degradation of activity. The results were generally similar to the ones seen in shake flasks (Fig. 6). It has been reported in the literature (Panova 


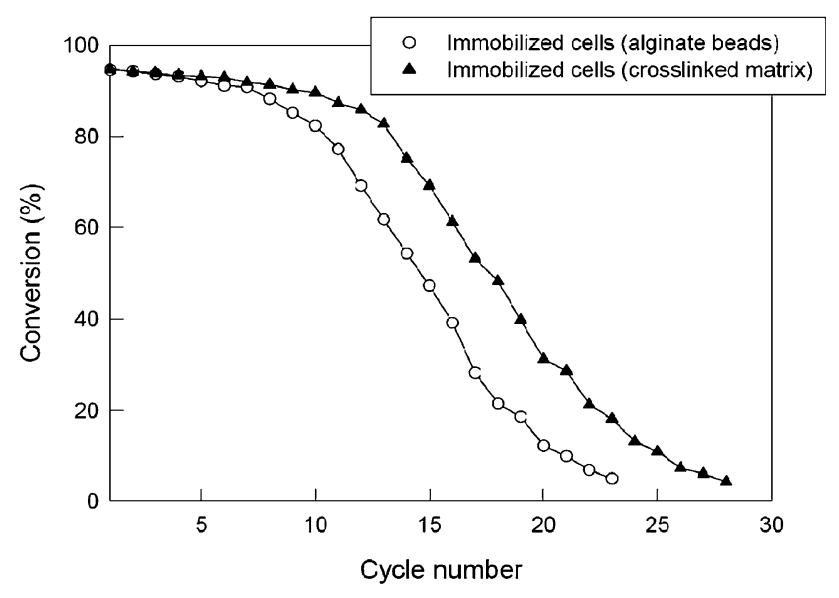

Fig. 8 Effect of number of reuse cycles on the conversion of mandelonitrile by immobilized bead biocatalyst in the packed bed reactor

et al. 2007) that whole cells of recombinant E. coli expressing nitrilase from $A$. faecalis were immobilized in the $\kappa$-carrageenan beads crossed linked with glutaraldehyde and PEI and the beads were quite stable for at least 50 recycles. In other studies, alginate matrix was also used for the production of 3-hydroxyvaleric acid (Wu et al. 2007) and $p$-methoxy phenyl acetic acid (Chen et al. 2008). Stirred tank and packed bed reactors with the immobilized nitrilase adsorbed by hydrophobic and ion exchange interaction were also studied for the transformation reactions (Martínková et al. 2009). The matrix-encapsulated recombinant cells having nitrilase activity from $A$. faecalis were used for the synthesis of ammonium glycolate in CSTR with a conversion efficiency of 98-99\% (Panova et al. 2007).

\section{Conclusions}

Alginate bead catalysts of immobilized cells of a nitrilasecontaining recombinant $E$. coli could be used successfully for stereo-selective hydrolysis of mandelonitrile to $(R)-(-)$-mandelic acid. Under optimal conditions $\left(40{ }^{\circ} \mathrm{C}\right.$, $\mathrm{pH} 8,20 \mathrm{mg}$ cells per $\mathrm{mL}$ of beads) the conversion at 60 min exceeded $90 \%$ both in suspensions of the catalyst $(1 \mathrm{~g} / \mathrm{mL}$ beads concentration) and in packed beds containing it. In the packed bed, a substrate feed concentration of up to $200 \mathrm{mM}$ could be used at a flow rate of $20 \mathrm{~mL} / \mathrm{min}$ (residence time of $58.5 \mathrm{~min}$ ) while attaining a conversion of nearly $93 \%$. The enantiomeric purity of the product was always close to $100 \%$. The packed bed could be used repeatedly for up to 12 cycles of operation $(1 \mathrm{~h}$ duration per cycle) without a significant loss of the ability to convert the substrate.
Acknowledgments The authors gratefully acknowledge the financial assistance provided by CSIR and DBT, Government of India, to carry out this study.

Open Access This article is distributed under the terms of the Creative Commons Attribution License which permits any use, distribution, and reproduction in any medium, provided the original author(s) and the source are credited.

\section{References}

Banerjee A, Sharma R, Banerjee UC (2002) The nitrile degrading enzymes: current status and future prospects. Appl Microbiol Biotechnol 60:33-44

Banerjee A, Kaul P, Banerjee UC (2006) Enhancing the catalytic potential of nitrilase from Pseudomonas putida for stereoselective nitrile hydrolysis. Appl Microbiol Biotechnol 72:77-87

Banerjee A, Dubey S, Kaul P, Barse B, Piotrowski M, Banerjee UC (2009) Enantioselective nitrilase from Pseudomonas putida: cloning, heterologous expression and bioreactor studies. Mol Biotechnol 41:35-41

Ben-Bassat A, Walls AM, Plummer MA, Sigmund AE, Spillan WL, DiCosimo R (2008) Optimization of biocatalyst specific activity for glycolic acid production. Adv Synth Catal 350:1761-1769

Bucko M, Vikartovska A, Lacik I, Kollarikova G, Gemeiner P, Brygin M, Patoprsty V (2005) Immobilization of a whole-cell epoxide-hydrolyzing biocatalyst in sodium alginate-cellulose sulfate-poly(methylene-co-guanidine) capsules using a controlled encapsulation process. Enzyme Microb Technol $36: 118-126$

Chen J, Zheng YG, Shen YC (2008) Biosynthesis of p-methoxyphenylacetic acid from $p$-methoxyphenylacetonitrile by immobilized Bacillus subtilis ZJB-063. Process Biochem 43:978-983

Givry S, Prevot V, Duchiron F (2008) Lactic acid production from hemicellulosic hydrolyzate by cells of Lactobacillus bifermentans immobilized in Ca-alginate using response surface methodology. World J Microbiol Biotechnol 24:745-752

He Y, Xu J, Xu Y, Ouyang LM, Pan J (2007) Biocatalytic synthesis of $(R)$-(-)-mandelic acid from racemic mandelonitrile by a newly isolated nitrilase-producer Alcaligenes sp. ECU0401. Chin Chem Lett 18:677-680

He Y, Zhang Z, Xu J, Liu Y (2010) Biocatalytic synthesis of (R)-(2)mandelic acid from racemic mandelonitrile by cetyltrimethylammonium bromide-permeabilized cells of Alcaligenes faecalis ECU0401. J Ind Microbiol Biotechnol 37:741-750

Kaplan O, Nikolaou K, Pisvejcova A, Martinkova L (2006) Hydrolysis of nitriles and amides by filamentous fungi. Enzyme Microb Technol 38:260-264

Kaul P, Banerjee UC (2008) Predicting enzyme behavior in nonconventional media: correlating nitrilase function with solvent properties. J Ind Microbiol Biotechnol 35:713-720

Kaul P, Banerjee A, Mayilraj S, Banerjee UC (2004) Screening for enantioselective nitrilases: kinetic resolution of racemic mandelonitrile to $(R)-(-)$-mandelic acid by new bacterial isolates. Tetrahedron Asymm 15:207-211

Kinbara K, Sakai K, Hashimoto Y, Nohira H, Saigo K (1996) Design of resolving reagents: $\mathrm{p}$-substituted mandelic acids as resolving reagents for 1-arylalkylamines. Tetrahedron Asymm 7:15391542

Kiziak C, Conradt D, Stolz A, Mattes R, Klein J (2005) Nitrilase from Pseudomonas fluorescens EBC191:cloning and heterologous expression of the gene and biochemical characterization of the recombinant enzyme. Microbiology 15:3639-3648

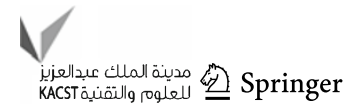


Kope HH, Tsantrizos YS, Fortin JA, Ogilive KK (1991) $p$-Hydroxybenzoylformic acid and $(R)-(-)-p$-hydroxymandelic acid, two antifungal compounds isolated from the liquid culture of the ectomycorrhizal fungus Pisolilithus arhizus. Can J Microbiol $37: 258-264$

Kumar S, Mohan U, Kamble AL, Pawar S, Banerjee UC (2010) Cross-linked enzyme aggregates of recombinant Pseudomonas putida nitrilase for enantioselective nitrile hydrolysis. Bioresour Technol 17:6856-6858

Ley JP, Bertram HJ (2001) Synthesis of polyhydroxylated aromatic mandelic acid amides and their antioxidative potential. Tetrahedron 57:1277-1282

Martinkova L, Mylerova V (2003) Synthetic applications of nitrileconverting enzymes. Curr Org Chem 7:1279-1295

Martínková L, Vejvoda V, Kaplan O, Kubác D, Malandra A, Cantarella M, Bezouska K, Kren V (2009) Fungal nitrilases as biocatalysts: recent developments. Biotechnol Adv 6:661-670

Mills J, Schmiegel KK, Shaw WN (1983) Phenethanolamines, compositions containing the same and method for effecting weight control. Eli Lilly and Company. US. Pat. US 4391826

Miyamoto K, Ohta H (1992) Enantioselective oxidation of mandelic acid using a phenylmalonate metabolizing pathway of a soil bacterium Alcaligenes bronchisepticus Ku1201. Biotechnol Lett 14:363-366

Mollard C, Moali C, Papamicae C, Damblon C, Vessilier S, Amicosante G, Schofield CJ, Galleni M, Frere JM, Roberts GCK (2001) Thiomandelic acid, a broad spectrum inhibitor of zinc $\beta$-lactamases. J Biol Chem 276:45015-45023

Naik S, Kaul P, Barse B, Banerjee A, Banerjee UC (2008) Studies on the production of enantioselective nitrilase in a stirred tank bioreactor by Pseudomonas putida MTCC 5110. Bioresour Technol 99:26-31

Niladevi K, Prema P (2008) Immobilization of laccase from Streptomyces psammoticus and its application in phenol removal using packed bed reactor. World J Microbiol Biotechnol 24:1215-1222

Oda S, Kikuchi Y, Nanishi Y (1992) Synthesis of optically active mandelic acid via microbial oxidation of racemic 1-phenyl-1,2ethanediol. Biosci Biotechnol Biochem 56:1216-1220

Panova A, Mersinger LJ, Liu Q, Foo T, Roe DC, Spillan WL, Sigmund AE, Ben-Bassat A, Wagner LW, O'Keefe DP, Wu S, Petrillo KL, Payne MS, Breske ST, Gallagher FG, DiCosimo R (2007) Chemoenzymatic synthesis of glycolic acid. Adv Synth Catal 349:1462-1474

Patterson MAK, Szajewski RP, Whitesides GM (1981) Enzymic conversion of alpha-keto aldehydes to optically active alpha hydroxy acids using glyoxalase I and II. J Org Chem 46:4682-4685

Rey P, Rossi JC, Taillades J, Gros G, Nore O (2004) Hydrolysis of nitriles using an immobilized nitrilase: applications to the synthesis of methionine hydroxyl analogue derivatives. J Agric Food Chem 52:8155-8162

Rustler S, Muller A, Windeisen V, Chmura A, Fernandes BCM, Kiziak C, Stolz A (2007) Conversion of mandelonitrile and phenylglycinenitrile by recombinant E. coli cells synthesizing a nitrilase from Pseudomonas fluorescens EBC191. Enzyme Microb Technol 40:598-606
Singh R, Banerjee A, Kaul P, Barse B, Banerjee UC (2005) Release of enantioselective nitrilase from Alcaligense faecalis MTCC 126: a comparative study. J Bioproc Biosys Eng 27:415-424

Surivet JP, Vatele JM (1998) First total synthesis of (-)-8-epi-9deoxygoniopypyrone. Tetrahedron Lett 39:9681-9682

Takeru I, Honda K, Shimizu S (2005) Whole organism biocatalysis. Curr Opin Chem Bio 9:174-180

Tang K, Yi J, Huang K, Zhang G (2009) Biphasic recognition chiral extraction: a novel method for separation of mandelic acid enantiomers. Chirality 21:390-395

Terreni M, Pagani G, Ubiali D, Lafuente RF, Mateo C, Guisan JM (2001) Modulation of penicillin acylase properties via immobilization techniques: one-pot chemoenzymatic synthesis of cephamandole from cephalosporin C. Bioorg Med Chem Lett 11:2429-2432

Varma RJ, Gaikwad BG (2010) Continuous phenol biodegradation in a simple packed bed bioreactor of calcium alginate-immobilized Candida tropicalis (NCIM 3556). World J Microbiol Biotechnol 26:805-809

Vejvoda V, Kaplan O, Klozová J, Masák J, Cejková A, Jirků V, Stloukal R, Martínková L (2006) Mild hydrolysis of nitriles by Fusarium solani strain O1. Folia Microbiol (Praha) 51:251-256

Won K, Kim SA, Kim KJ, Park HW, Moon SJ (2005) Optimization of lipase entrapment in Ca-alginate beads. Process Biochem 40:2149-2154

Wu S, Fogiel AJ, Petrillo KL, Hann EC, Mersinger LJ, DiCosimo R, O'Keefe DP, Ben-Bassat A, Payne MS (2007) Protein engineering of Acidovorax facilis 72W nitrilase for bioprocess development. Biotechnol Bioeng 97:689-693

Xiao MT, Huang YY, Shi XA, Guo YH (2005) Bioreduction of phenylglyoxylic acid to $(R)-(-)$-mandelic acid by Saccharomyces cerevisiae FD11b. Enzym Microbiol Technol 37:589-596

Xiao MT, Huang YY, Ye J, Guo YH (2008) Study on the kinetic characteristics of the asymmetric production of $(R)-(-)$-mandelic acid with immobilized Saccharomyces cerevisiae FD11b. Biochem Eng J 39:311-318

Xue YP, Xu SZ, Liu ZQ, Zheng YG, Shen YC (2011) Enantioselective biocatalytic hydrolysis of $(R, S)$-mandelonitrile for production of $(R)-(-)$-mandelic acid by a newly isolated mutant strain. J Ind Microbiol Biotechnol 38:337-345

Yadav GD, Sivakumar P (2004) Enzyme-catalysed optical resolution of mandelic acid via (RS)-methyl mandelate in nonaqueous media. Biochem Eng J 19:101-107

Yamamoto K, Oishi K, Fujimatsu I, Komatsu K (1991) Production of $(R)$-(-)-mandelic acid from mandelonitrile by Alcaligenes faecalis ATCC 8750. Appl Environ Microbiol 57:3028-3032

Zaneveld LJD, Anderson RA, Diao XH, Waller DP, Chany C, Feathergill K, Doncel G, Cooper MD, Herold B (2002) Use of mandelic acid condensation polymer (SAMMA), a new antimicrobial contraceptive agent, for vaginal prophylaxis. Fert Steril 78:1107-1115

Zhang ZJ, Pan J, Liu JF, Xu JH, He YC, Liu YY (2011) Significant enhancement of $(R)$-mandelic acid production by relieving substrate inhibition of recombinant nitrilase in toluene-water biphasic system. J Biotechnol 152:24-29 